\title{
Erratum to "Selected Legislation and Jurisprudence, European Court of Human Rights" [European Journal of Health Law 25 (2018) 459-468]
}

\author{
Joseph Dute \\ Professor of Health Law, Faculty of Law, Radboud University, Nijmegen, The \\ Netherlands
}

Due to an administrative error, the article published in the Selected Legislation and Jurisprudence, European Court of Human Rights section of issue 25(4) of the European Journal of Health Law on pages 459-468 (DOI: https://doi.org/ 10.1163/15718093-12540388; https://brill.com/view/journals/ejhl/25/4/articlep459_6.xml) contained text identical to that published in this section in issue 25(3). The correct text that should have been published is available overleaf. We apologise for this error. 


\section{Selected Legislation and Jurisprudence}

\section{European Court of Human Rights}

ECHR 2018/14 Case of Pocasovschi and Mihaila v. Moldovia and Russia, 29 May 2018, no. 1089/og (Second Section)

\section{The Facts $^{1}$}

The applicants were convicted by Moldovan courts and, at the time of the events, were serving their sentences in prison no. 8 situated in the town of Tighina (Bender), in the Transdniestrian region of the Republic of Moldova. The town is situated in the security zone under the control of peacekeepers from Moldova, Russia and the self-proclaimed "Moldavian Republic of Transdniestria" ("MRT"). Prison no. 8 is under the exclusive control of the Moldovan authorities. By October 2003, some 236 people were detained there; some of them, such as the applicants, were ill with tuberculosis.

In September 2002 the town cut off the prison's water, power and heating supplies, with water and electricity not being reconnected until February 2003. The prison was cut off again in July of the same year, with the "MRT authorities" insisting that the prison had to be closed down. The applicants remained at the prison throughout the period when the utilities were cut off. They were transferred to other prisons respectively in September 2004 and March 2004. They have both since been released on parole.

With the help of the Helsinki Committee for Human Rights in Moldova, the applicants and other detainees put pressure in 2003 and 2004 on the Moldovan authorities to improve conditions at the prison and to intervene with the "MRT authorities" to prosecute those responsible for cutting off its water and power, but no prosecution has taken place.

1 These summaries are based on the provisional text of the judgements of the European Court of Human Rights. These judgments are still subject to editorial revision before their reproduction in Reports of Judgments and Decisions. For the full provisional text, see: http://www .echr.coe.int. 
In March 2004 the Helsinki Committee launched civil compensations claim on behalf of detainees, including the applicants. The Bender Court of Appeal in June 2009 ultimately awarded the applicants 1,266 euros in compensation, acknowledging a breach of their rights on the grounds of inhuman conditions of detention. The court found that after the utilities had been turned off, the prison had no longer been able to offer food or proper treatment for tuberculosis. There had been no access to showers and only two hours of power per day, supplied by a low-power generator.

This summary is restricted to the issues raised under Article 3 of the Convention.

\section{The Law}

\section{Alleged Violation of Article 3 of the Convention}

The applicants complained regarding the inhuman conditions of detention at prison no. 8 in Tighina/Bender, contrary to Article 3 of the Convention, which forbids inhuman or degrading treatment.

The Court finds that both applicants have lodged their application against Russia outside the six-month time-limit. Therefore, the complaints against that country are inadmissible. It also finds that Moldova had full jurisdiction over the prison, even if the town itself was controlled by the "MRT".

The Court notes that the conditions of detention during September 2002April 2004 were considered by the domestic courts to be inhuman. Even though the Moldovan Government suggested that the authorities had taken action to improve the conditions of detention, their arguments refer to actions taken after February 2004, that is, close to the end of the applicants' detention in prison no. 8. The Court has no reason to depart from the domestic courts' assessment of the conditions of detention and finds, as did those courts, that prolonged detention in conditions where access to water, electricity, food, warmth and medication is severely limited amounts to inhuman treatment under Article 3 of the Convention.

What remains to be verified is whether, following the express acknowledgment of a violation of Article 3 and the award of compensation, the applicants can still claim to be victims of that violation by the Republic of Moldova.

It notes that the applicants complained only regarding the conditions of detention during the prison's disconnection from the utilities. The Court will take into account only the periods during which they were held in these conditions. There were two such periods: September 2002-February 2003, and July 
2003 until the dates of the applicants' transfer to other prisons. Accordingly, the applicants were held in inhuman conditions for approximately nineteen and thirteen months respectively.

Where, as in the present case, the victim status and therefore, the existence of a violation, is linked with the monetary redress afforded at domestic level, the Court's assessment necessarily involves comparison between the actual award and the amount that the Court would award in similar cases.

In this connection, the Court notes that the domestic courts awarded the applicants the equivalent of EUR 1,266 in respect of the breach of Article 3 . The Court considers that the sum awarded by the domestic courts is considerably below that generally awarded by the Court in cases in which it has found a violation of Article 3 in respect of the Republic of Moldova concerning conditions of detention, especially considering the particularly harsh conditions of the applicants' detention and the relatively long period during which they were held in such conditions.

In the light of the foregoing, the Court considers that the applicants can still claim to be victims of a violation of Article 3 of the Convention. Accordingly, the Moldovan Government's objection concerning the applicants' victim status is dismissed.

For these reasons, the Court, unanimously, holds that there has been a violation of Article 3 of the Convention by the Republic of Moldova in respect of both applicants.

ECHR 2018/15 Case of Kartvelishvili v. Georgia, 7 June 2018, no. 17716/o8 (Fifth Section)

\section{The Facts}

In October 2000, the applicant was convicted of murder and sentenced to nine years' imprisonment. While serving his sentence, he was also convicted of possessing a penknife, which was prohibited under prison regulations, and sentenced to a further three years in prison.

On 7 November 2007 the applicant complained to the prison administration of a high fever and a dry cough. Three days later het was transferred to the prison hospital. On 13 November 2007 he was diagnosed with pulmonary tuberculosis (TB), with the upper part of his left lung already seriously affected 
by the disease (in an advanced stage of disaggregation). The applicant occasionally coughed up blood. He was further diagnosed with viral hepatitis $\mathrm{C}$ (HCV), with the disease in its early stage at that time.

A panel of doctors of the prison hospital elaborated a treatment plan for the applicant's TB and HCV. Notably, given the stages of the two diseases at that time and the known side-effects of the anti-TB and anti-H CV drugs, the doctors recommended that the applicant first be provided with anti-TB medication under the Dотs programme (Directly Observed Treatment, Short-course - the treatment strategy for detection and cure of TB recommended by the World Health Organisation). Only upon completion of the anti-TB treatment, could the applicant start receiving, in the doctors' view, antiviral drugs for his HCv.

This summary is restricted to the issues raised with regard to the provision of medical care in prison.

\section{The Law}

\section{Alleged Violation of Article 3 of the Convention}

Relying on Article 3 (prohibition of inhuman or degrading treatment), the applicant alleged that he had not been provided with appropriate medical care for his various diseases in prison.

The Court reiterates that when assessing the adequacy of medical care in prison, it must, in general, show sufficient flexibility when defining the required standard of health care, which must accommodate the legitimate demands of imprisonment but remain compatible with human dignity and the due discharge of positive obligations by States. In that regard, it is incumbent upon the relevant domestic authorities to ensure, in particular, that diagnosis and care have been prompt and accurate, and that supervision by proficient medical personnel has been regular and systematic and involved a comprehensive therapeutic strategy. The mere fact of a deterioration of an applicant's state of health, albeit capable of raising, at an initial stage, certain doubts concerning the adequacy of the applicant's treatment in prison, cannot suffice by itself for a finding of a violation of the State's positive obligations under Article 3 of the Convention, if, otherwise, it can be established that the relevant domestic authorities have in a timely fashion provided all the reasonably available medical care in a conscientious effort to hinder the development of the illness in question. A penal authority's failure to keep comprehensive records concerning a 
detained applicant's state of health or a respondent Government's failure to submit such records in their entirety would consequently allow the Court to draw inferences as to the merits of the applicant's allegations of a lack of adequate medical care.

Following notification of the present application, the Government submitted a copy of the medical file on the applicant's treatment, fully accounting for the period in question. In other words, by disclosing all the information necessary for the assessment of the quality of the treatment in issue, the Government have discharged their burden of proof, assisting the Court in its task of factual determination, and the applicant's subsequent objections must be treated with caution.

Regarding the applicant's medical file, the Court observes that the Prison Service responded promptly to the applicant's first medical complaint of 7 November 2007, by transferring him, as early as 10 November 2007, to the prison hospital. During his time in hospital, which lasted three months, the prison's medical staff took good care of the applicant by having him undergo various laboratory screenings and tests and consultations with various medical specialists. Having been diagnosed with TB and HCV, the relevant specialists set out a particular plan of treatment for the applicant, which was then duly implemented by the prison medical staff. As a result of that treatment, the applicant's condition related to his TB significantly improved, which resulted in his discharge from the prison hospital on 12 February 2008. After the applicant's discharge from the prison hospital, the medical personnel of prison no. 7 continued providing him with the relevant antibiotics for an additional five months. Throughout the period of his treatment, both on an inpatient and outpatient basis, the Prison Service regularly arranged for the applicant's sputum culture and sensitivity to be tested by the National Centre for Tubercular and Lung Diseases. The results of those tests confirmed the suitability of the ongoing treatment. All in all, upon completion of the relevant treatment plan, the applicant was cured of $\mathrm{TB}$, a fact that was confirmed by the repeated sets of medical tests conducted between December 2008 and February 2010 showing no traces of the disease in his system.

The Court attaches further significance to the fact that the Prison Service did not leave the applicant's HCV untreated either. Thus, as early as November 2007 , the relevant medical specialists opined that, given an incompatibility between the side-effects of anti-H CV drugs and the needs of the treatment against $\mathrm{TB}$, as well as the fact that at that time the applicant's HCV was in a very early stage, the treatment for the latter infection should be postponed until after the completion of the anti-TB treatment. In November and May 2007 and June 
2010, additional biochemical tests of the applicant's blood samples confirmed that the HCV's activity in the applicant's organism was consistently low. Being guided by the professional caution of the attending doctors, who informed the applicant of the possible side-effects of the anti-HCV treatment, the applicant made, in June 2010, a fully informed decision about the further postponement of the proposed treatment. All those circumstances clearly suggest that the Prison Service made use of a truly comprehensive therapeutic strategy to address the applicant's HCV.

In those circumstances, the Court considers that the Prison Service showed a sufficient degree of diligence, providing the applicant with sufficiently prompt, regular and strategically planned treatment for his various health issues. It follows that the applicant's complaint is manifestly ill-founded and must be rejected in accordance with Article $35 \S \S 3$ (a) and 4 of the Convention.

Joseph Dute

Professor of Health Law, Faculty of Law, Radboud University, Nijmegen, The Netherlands 